Kansas State University Libraries

New Prairie Press

Center for Engagement and Community

Development

Rural Grocery Summit

\title{
Shopper Marketing Nutrition Interventions
}

Colin Payne

New Mexico State University

Follow this and additional works at: https://newprairiepress.org/cecd (c) (i) (9)

This work is licensed under a Creative Commons Attribution-Noncommercial-No Derivative Works 4.0 License.

Payne, Colin (2014). "Shopper Marketing Nutrition Interventions," Center for Engagement and Community Development. https://newprairiepress.org/cecd/ruralgrocery/2014/26

This Event is brought to you for free and open access by the Conferences at New Prairie Press. It has been accepted for inclusion in Center for Engagement and Community Development by an authorized administrator of New Prairie Press. For more information, please contact cads@k-state.edu. 
Shopper Marketing Nutrition Interventions

Collin R. Payne, PhD

New Mexico State University

Department of Marketing

Rural Grocery Summit
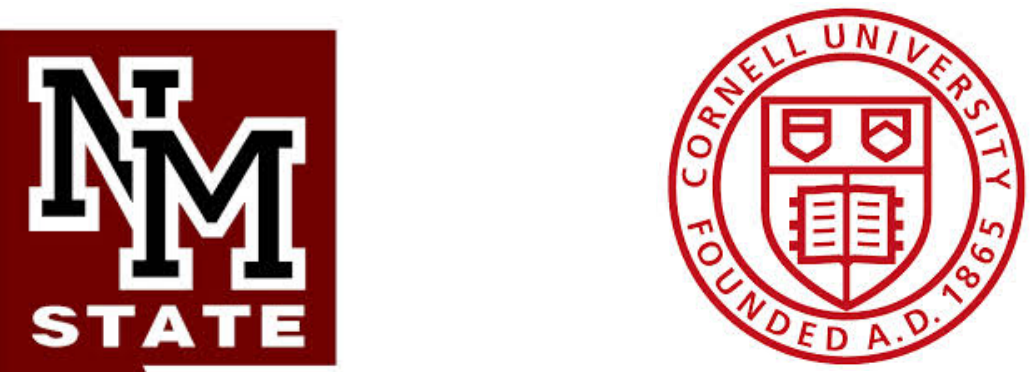


\section{Behavioral Economic Approaches to Grocery Store Health Interventions}

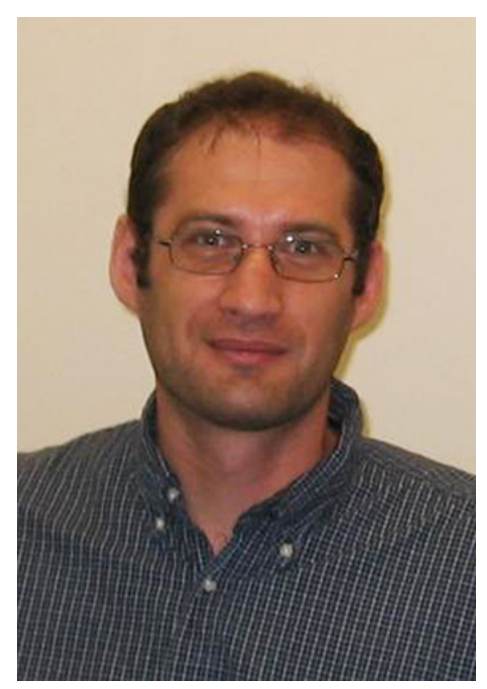

Mihai Niculescu, PhD New Mexico State University Marketing

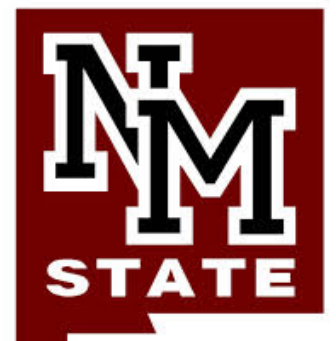

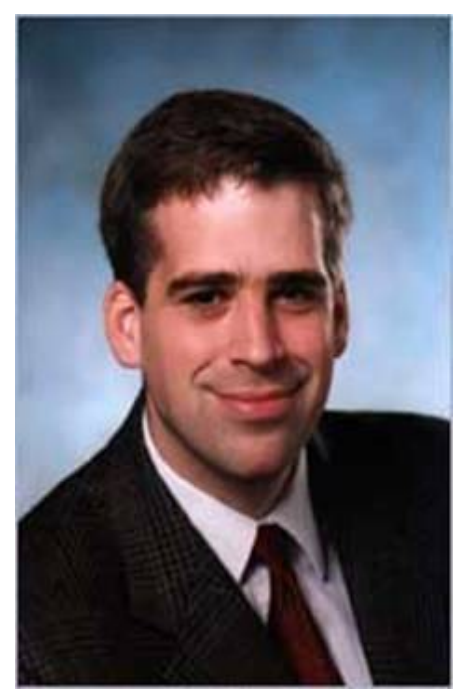

David Just, PhD

Cornell University Applied Economics

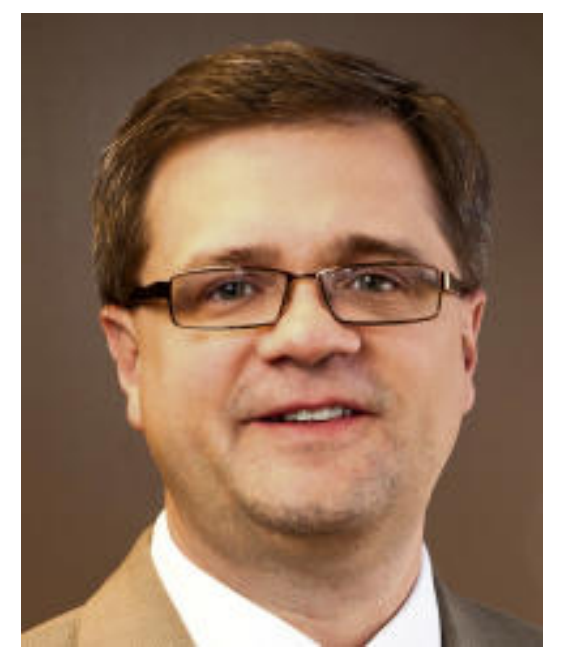

Michael P Kelly, PhD Chief Grant Officer Paso del Norte Health Foundation

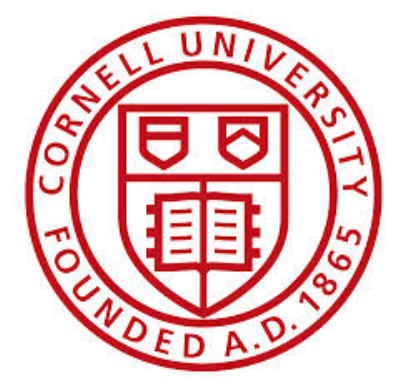

Y.XY PASO DEL NORTE HEALTH

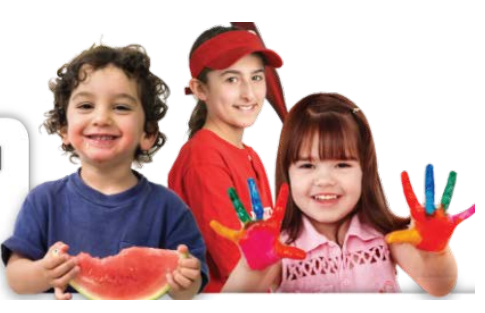




\section{Who Are We? \\ NMSU Consumer Behavior Lab (http://cobelab.nmsu.edu/)}

- Multidisciplinary Perspectives on Consumer Health

- Collaborators from Health, Psychology, Anthropology, Management, Economics, Agriculture, Neuroscience

- Understand How Marketing Can Help both Business \& Consumer Health

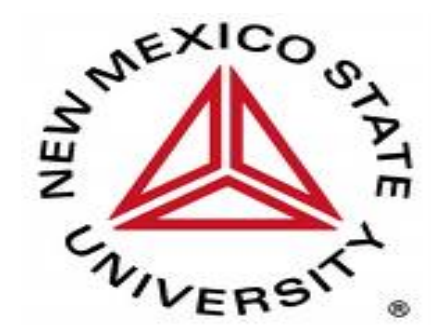




\section{The Whole Presentation in 1 Slide}

- 1. What is Shopper Marketing?

- 2. Improve Nutrition

- 3. Keep constant shopper budgets

- 4. Increase store profitability

- 5. What's next? 
What is Shopper Marketing?

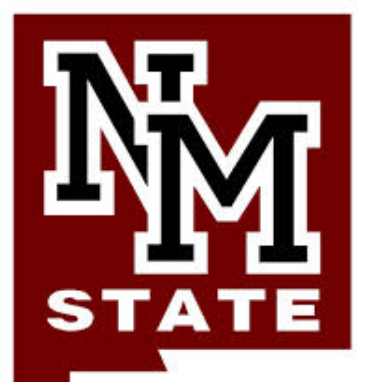


Shopper Marketing Nutrition

\section{Interventions}

1. Improve Nutrition ( $60 \%$ all food purchases)

2. Keep constant shoppers' budget

3. Increase store profitability

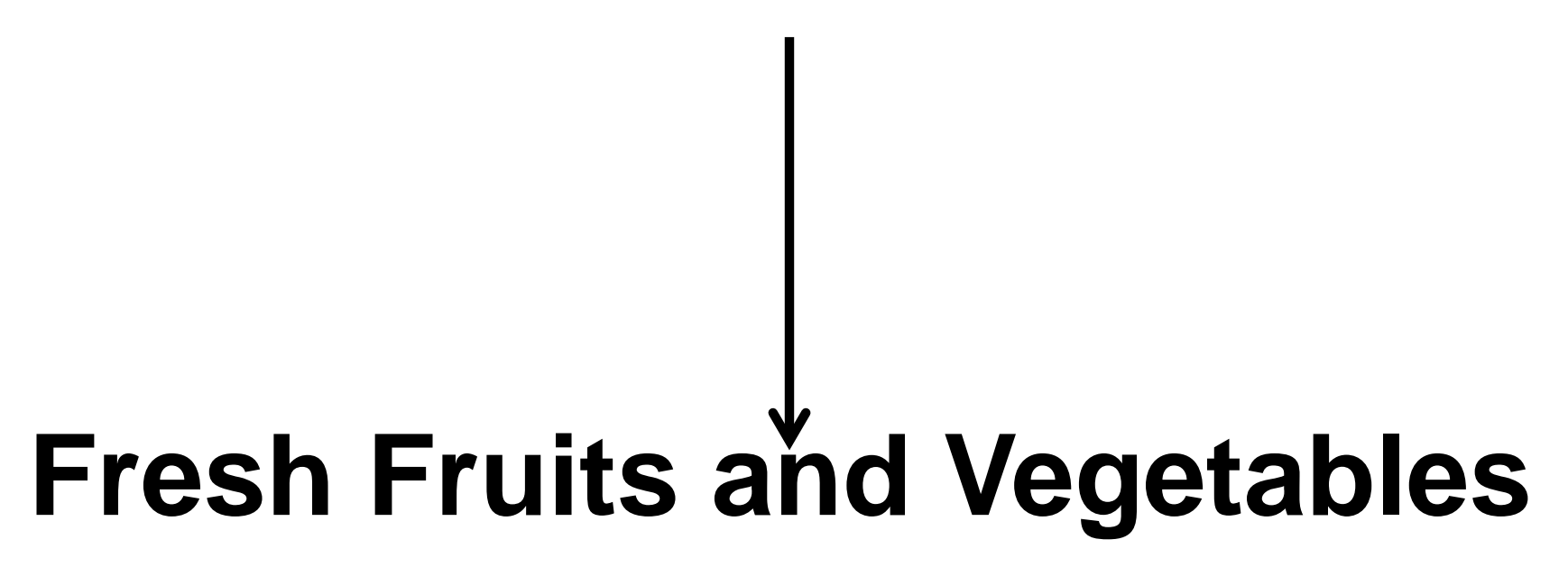




\section{Improve Nutrition}

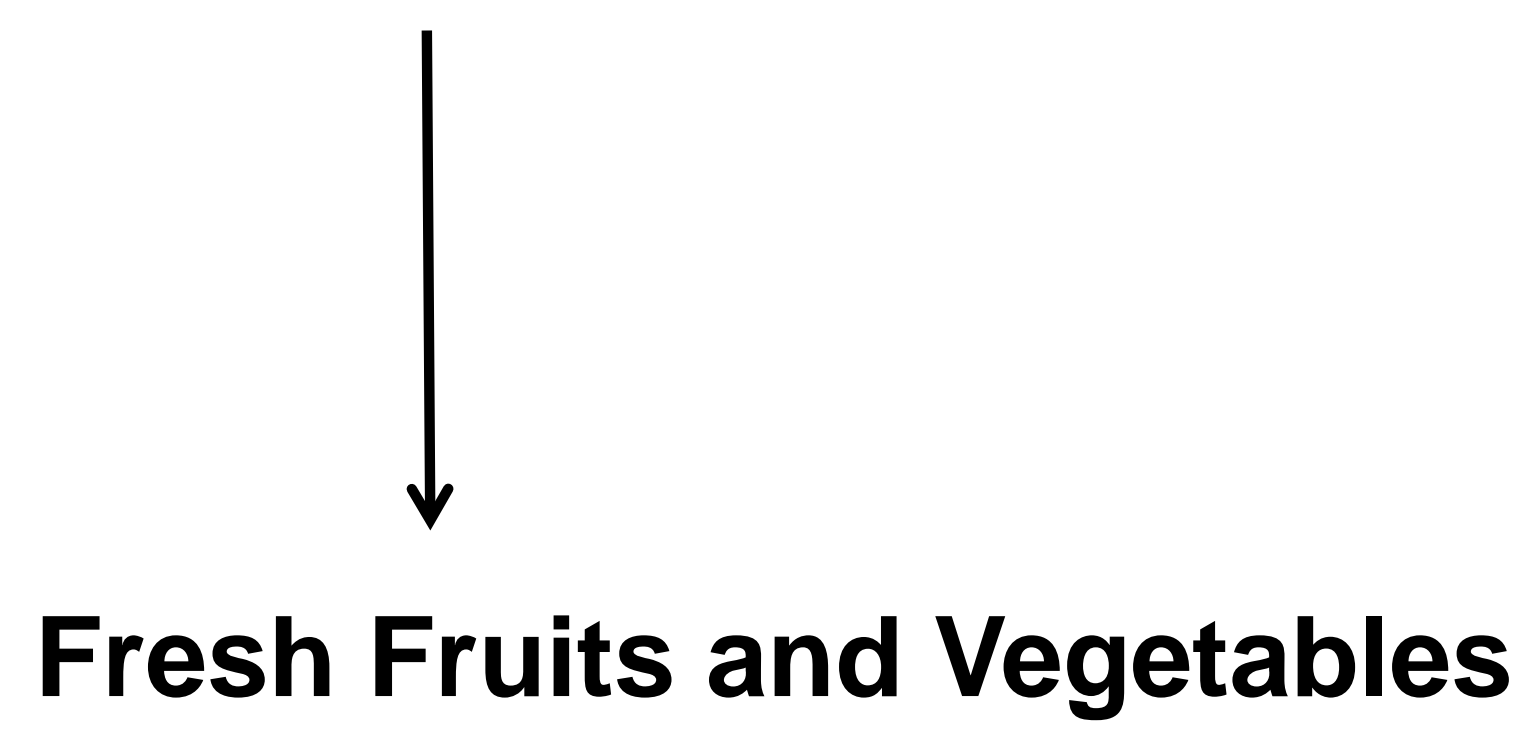

Dramatically below recommended purchase and intake (Volpe and Okrent, 2012)
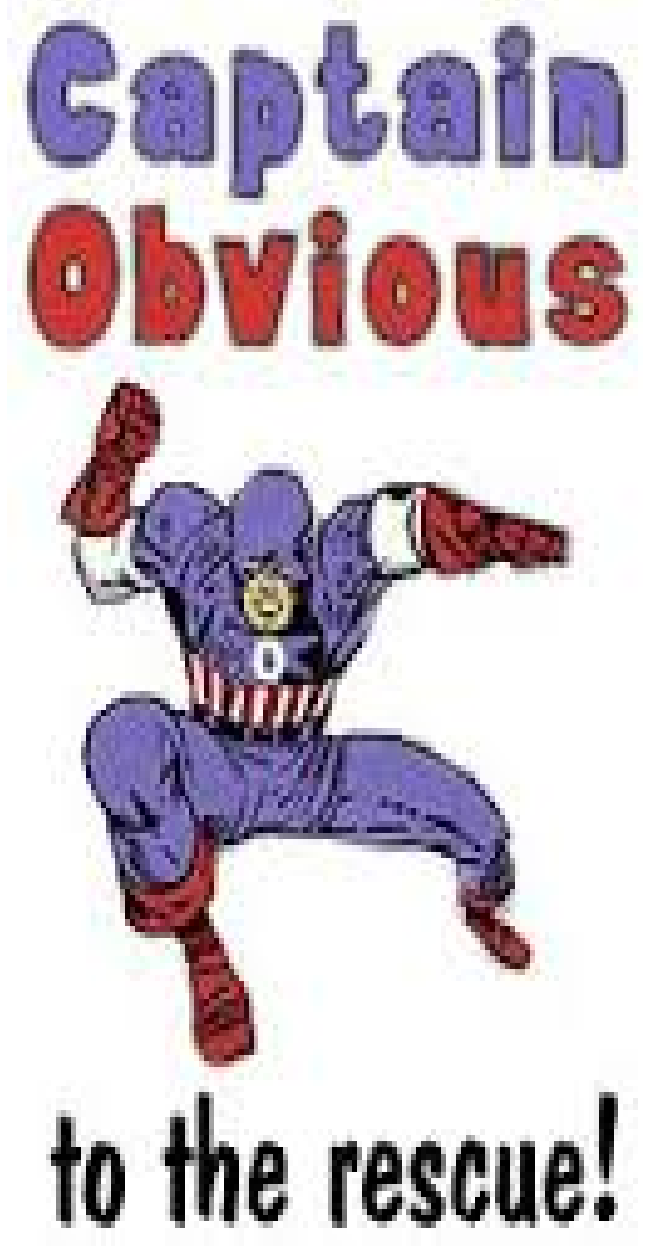


\section{Improve Nutrition:}

\section{Direct and Indirect Attempts}

Crucial Events for FOP

- FDA and FTC worried public not getting nutritional information to make healthy choices.

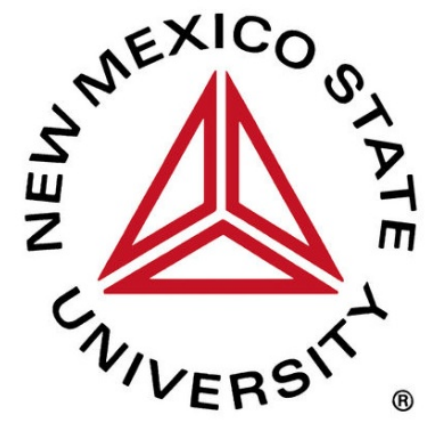

- Nutrition Labeling and Education ACT 1990 (1993)-"Nutrition Facts Panel (NFP)"

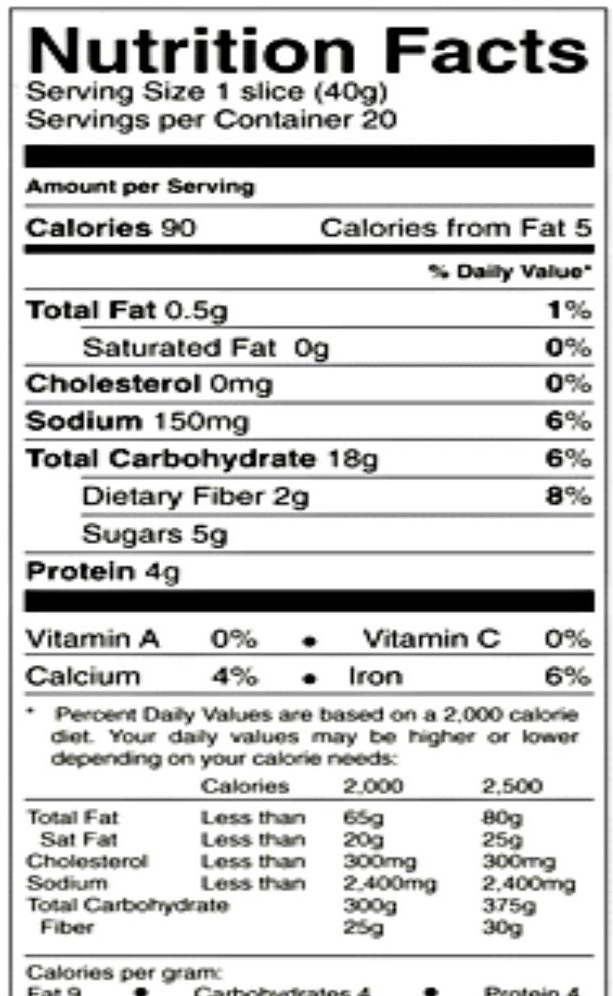




\section{Improve Nutrition:}

\section{Direct and Indirect Attempts}

Crucial Events for FOP

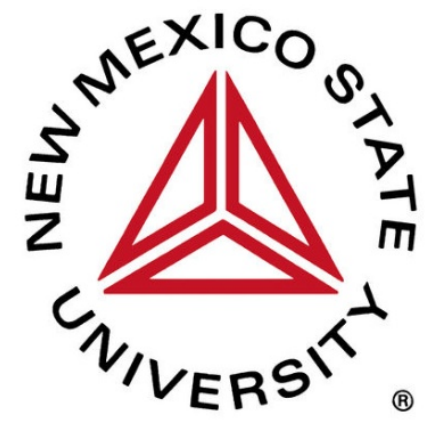

3. Commercial firms' natural response to NFP:

- Engage in federally protected commercial speech

- Within guidelines, emphasize food's relative health benefit downplaying nutritional detriments.

Examples...

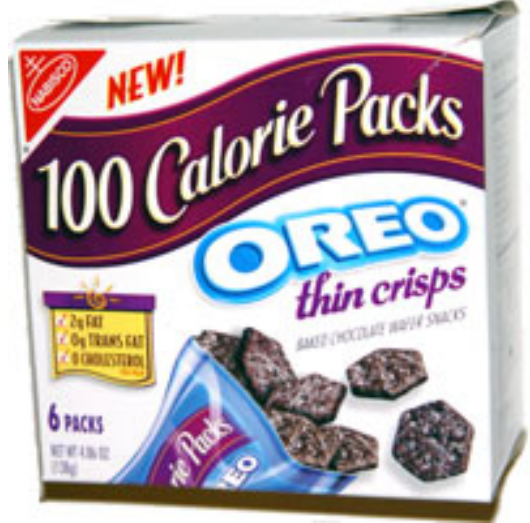

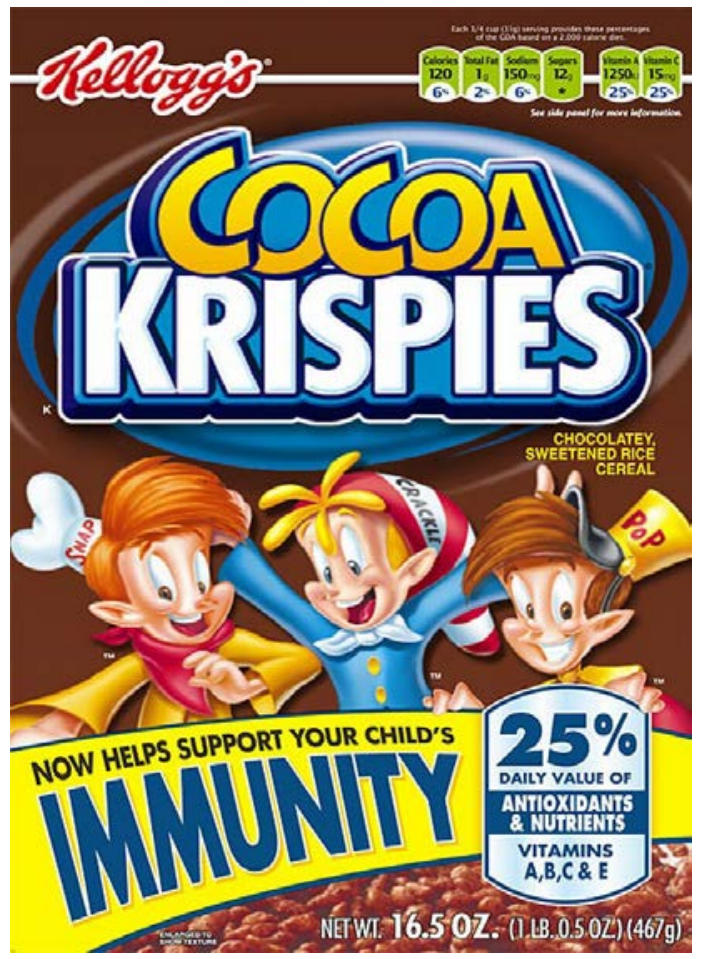

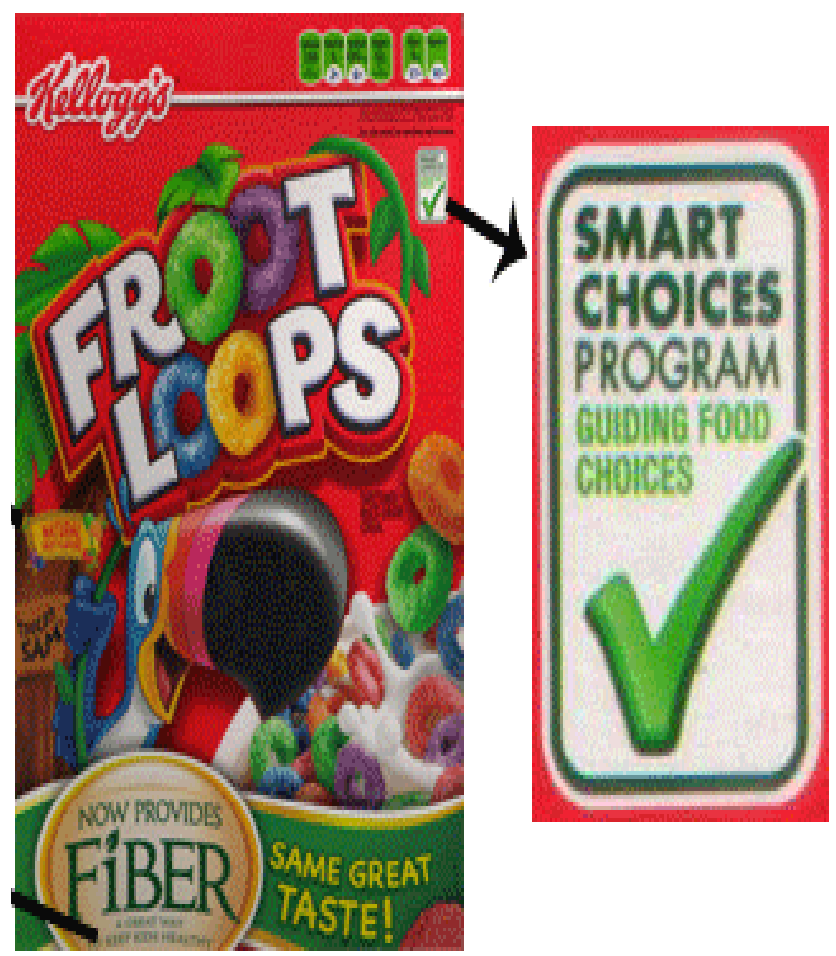




\section{Improve Nutrition:}

\section{Direct and Indirect Attempts}

Crucial Events for FOP

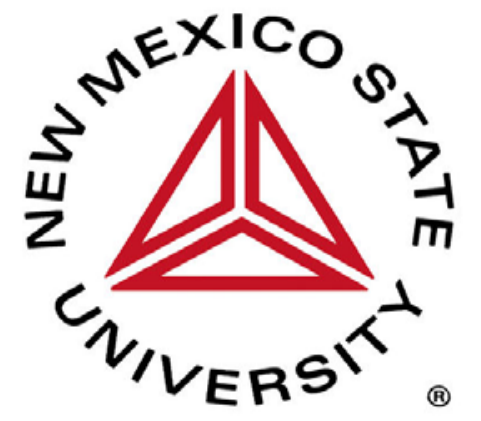

\section{Trade organization (grocery manufacturer association)}

FOPs (January 2011) "Facts Up Front"...
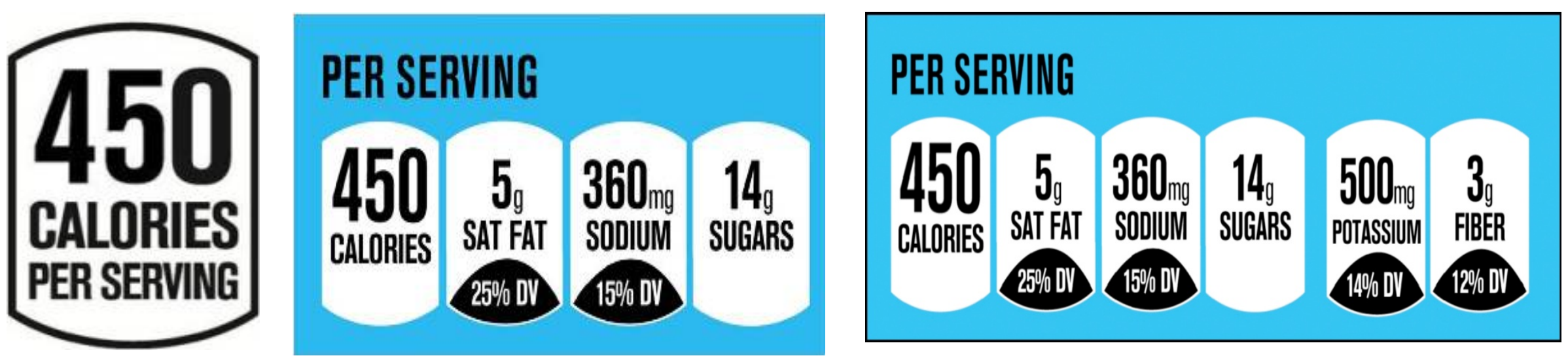

Not as good as heuristic-based traffic light symbols

(Roberto, et. al., American Journal of Preventative Medicine) 


\section{Improve Nutrition:}

\section{Direct and Indirect Attempts}
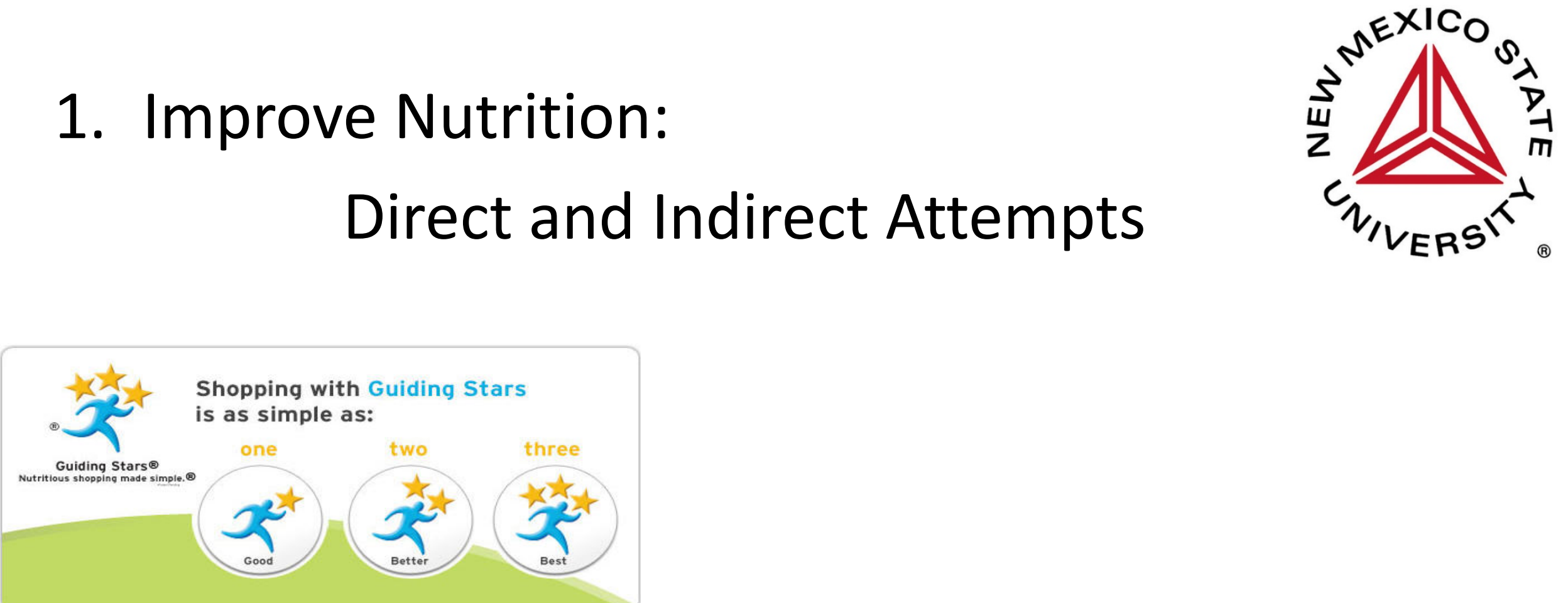

ReSUltS? (Martin, 2007, New York Times; Sutherland,, Kaley, and Fischer 2010):

\begin{tabular}{|l|l|}
\hline Foud' & Increase? \\
\hline Fat Free Milk & $+1 \%$ \\
\hline
\end{tabular}

Fruit \&

$0 \%$

Vegetables

All "more

$1.4 \%$

healthy" 
2. Keep constant shoppers' budget
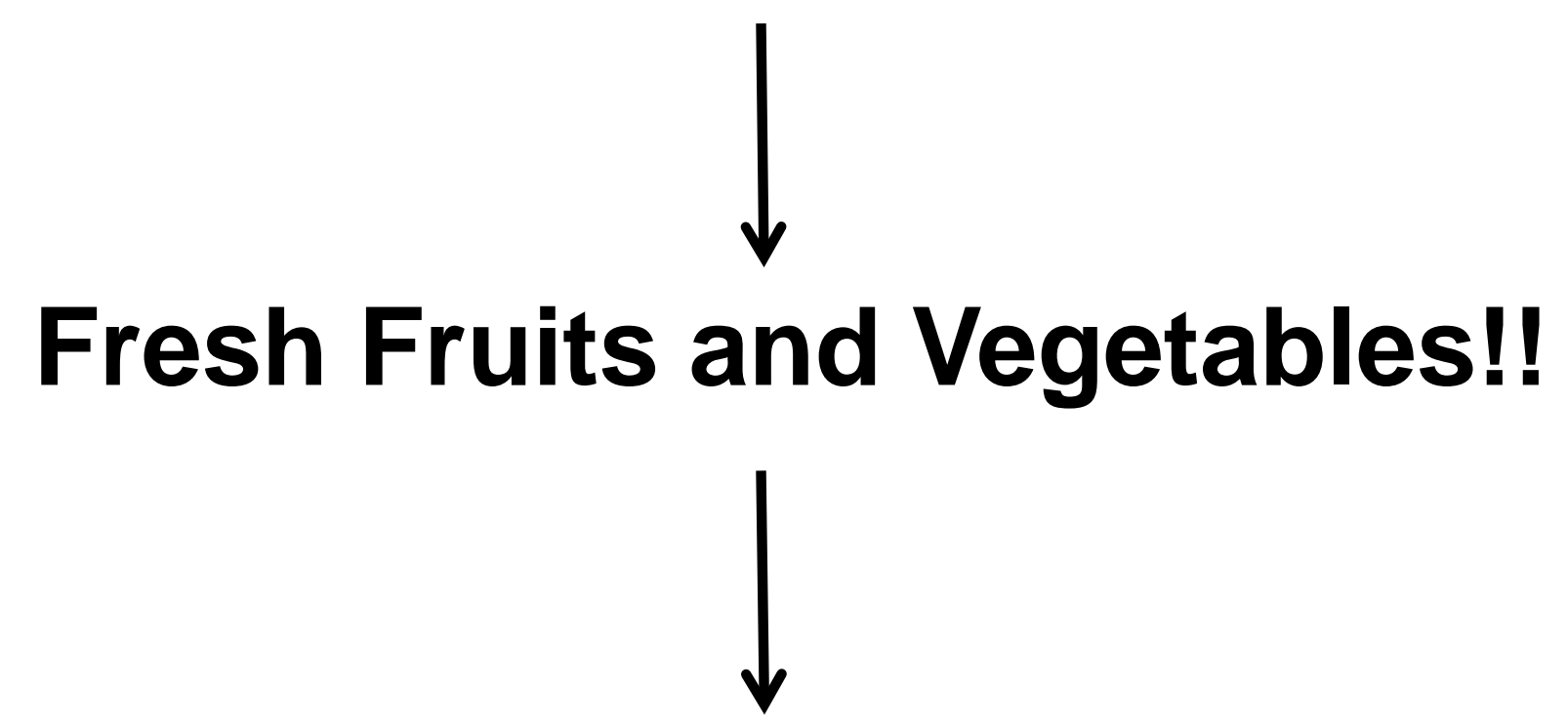

- Budgets fixed @ store. SM doesn't increase dollar volume it shifts existing dollars to higher margin fruit and vegetables 


\section{Keep constant shoppers' budget}

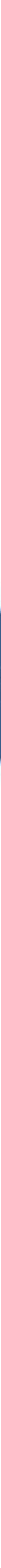




\section{Keep constant shoppers' budget}

- Planned purchases deliberative and committed $-50 \%$ of purchases

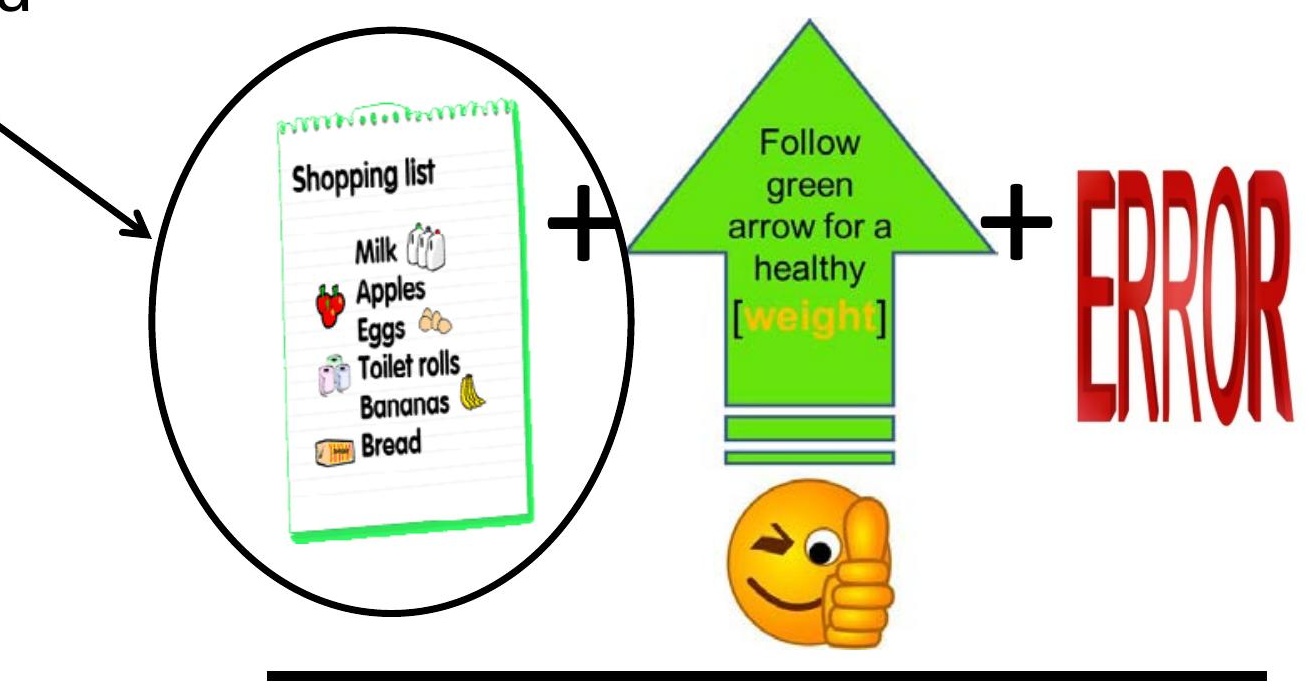

Grocery Store Expenditures 


\section{Keep constant shoppers' budget}

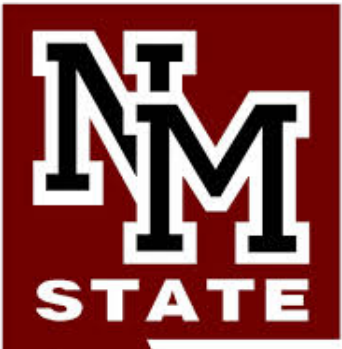

$50 \%$ of all purchases unplanned purchases

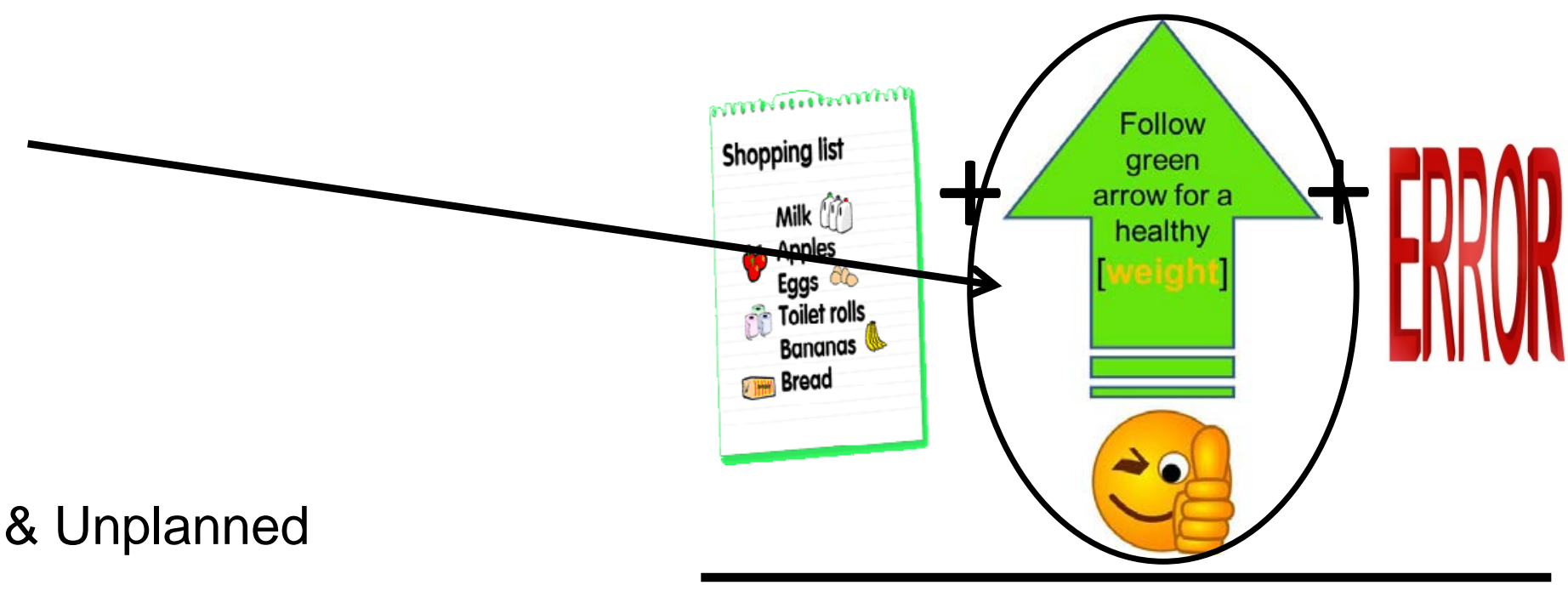

- Forgotten Needs \& Unplanned wants

- Consumers report bringing money to the store for this purpose

Grocery Store Expenditures 
2. Keep constant shoppers' budget

- Government benefit inefficiencies

- $(22 \%$ of F\&V WIC benefit unused)

- (only 20\% SNAP used for $F \& V$ )

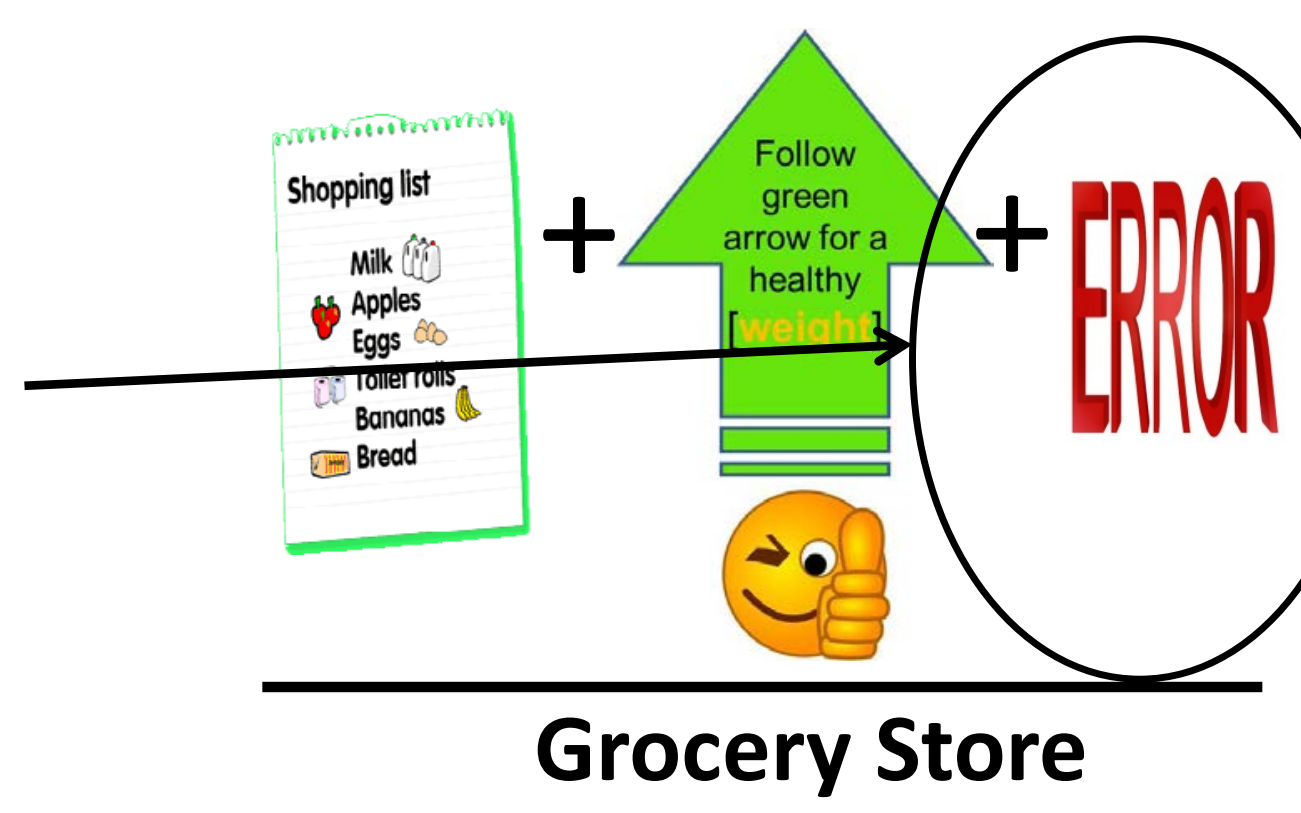

Expenditures 


\section{Keep constant shoppers' budget}

We focus our Shopper Marketing Efforts here

- Forgotten Needs \& Unplanned wants (easiest to change)

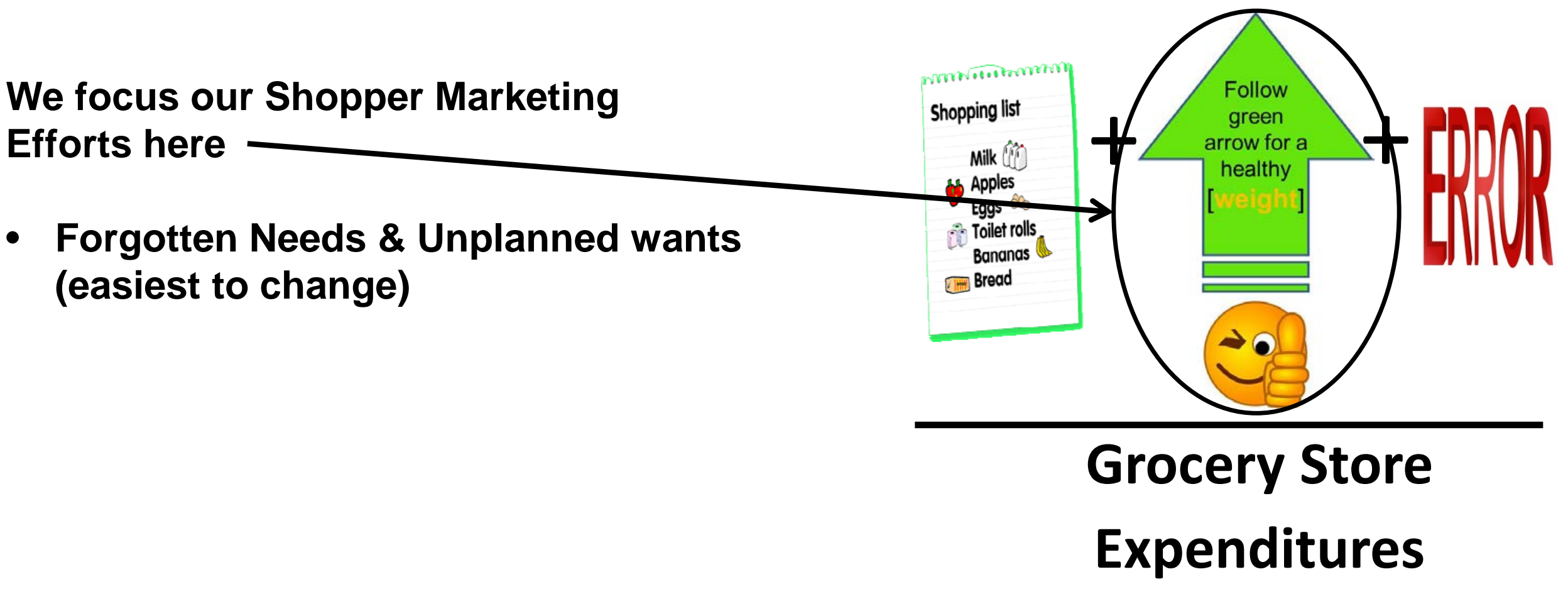


3. Increase store profitability
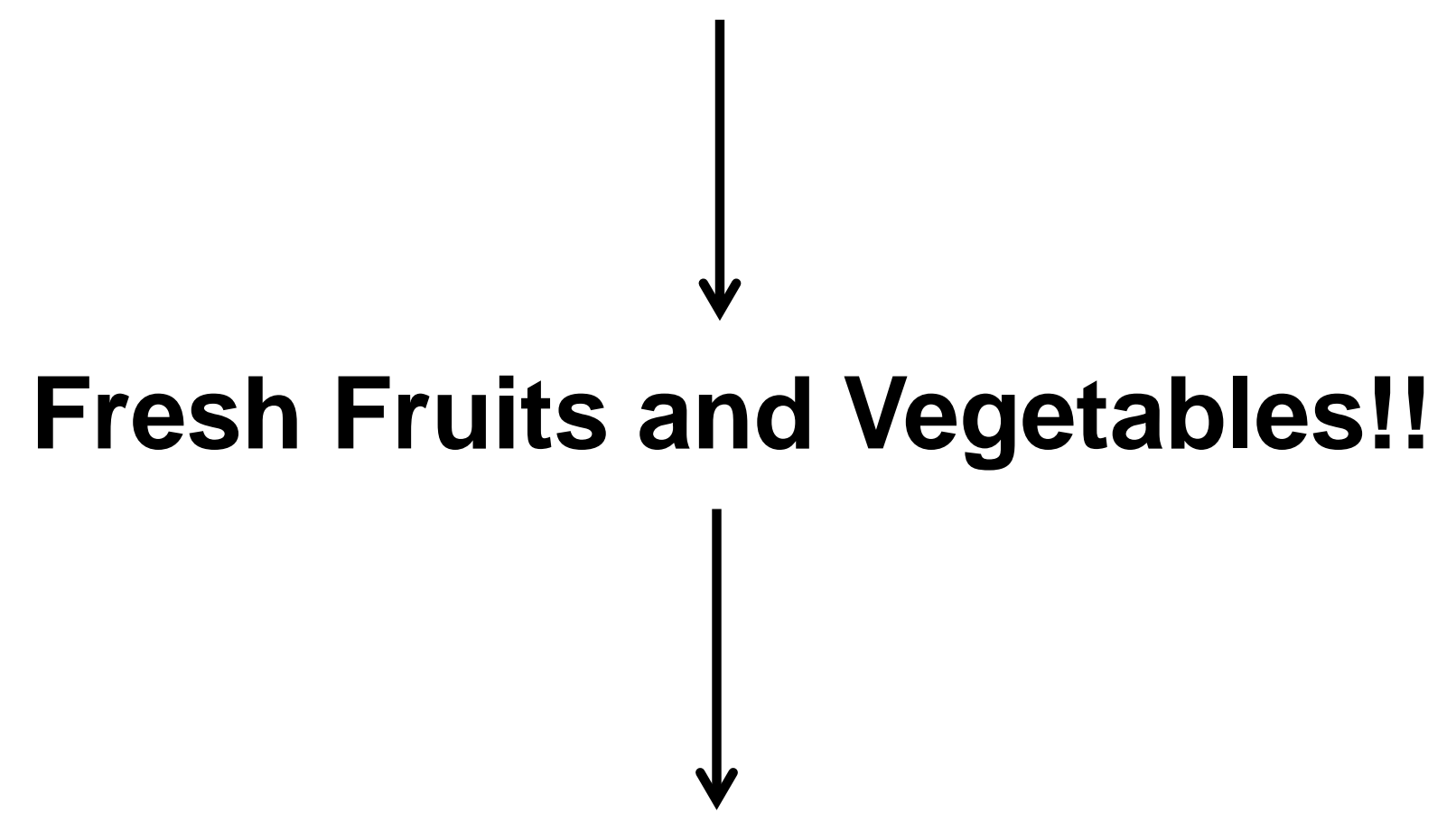

- Fresh F\&V generally higher margin ( 30\%). 


\section{Increase store profitability}

This is what shoppers face!
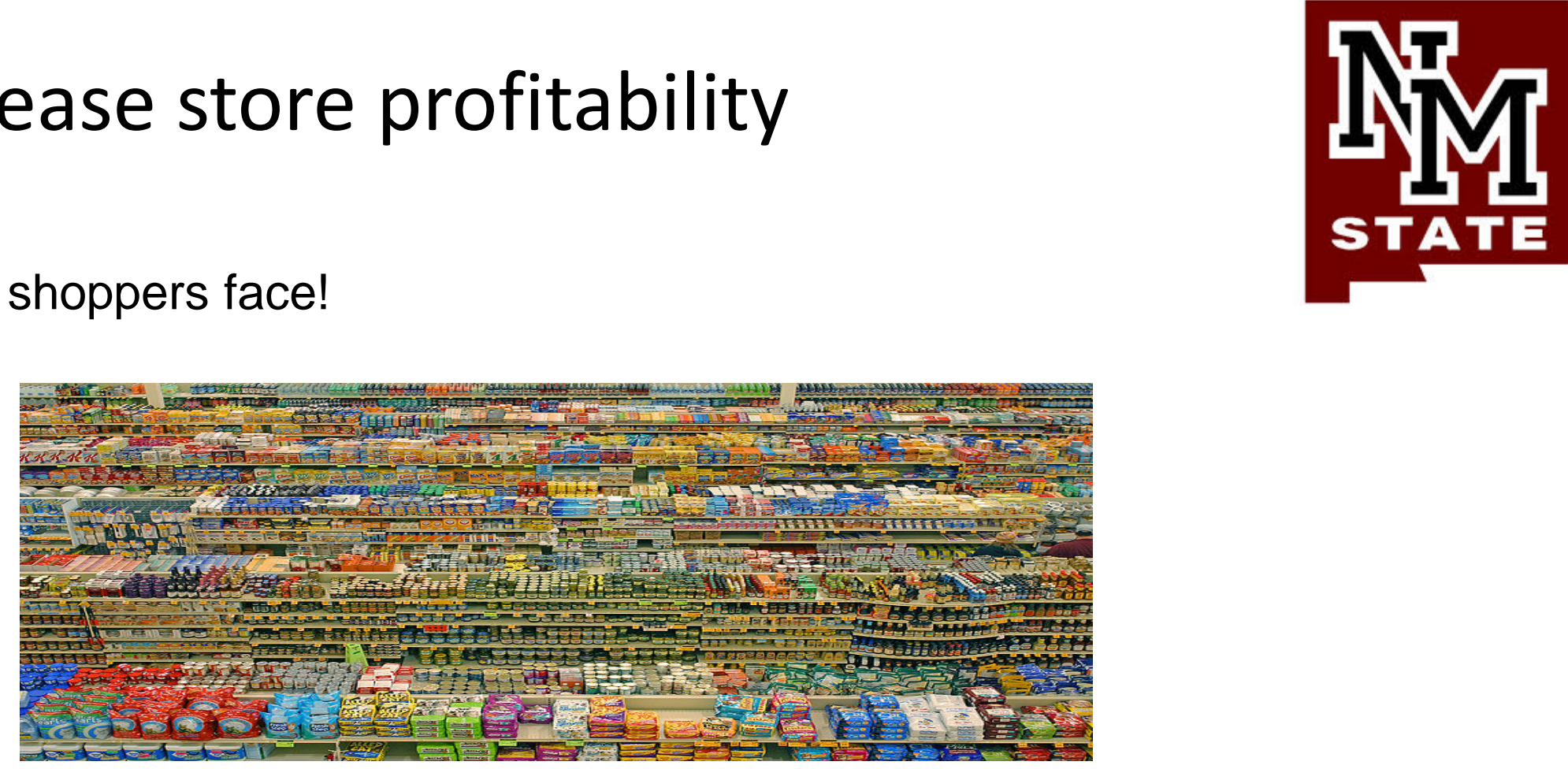

And this!!!

Can people use nutrition facts panels and "facts up front?"

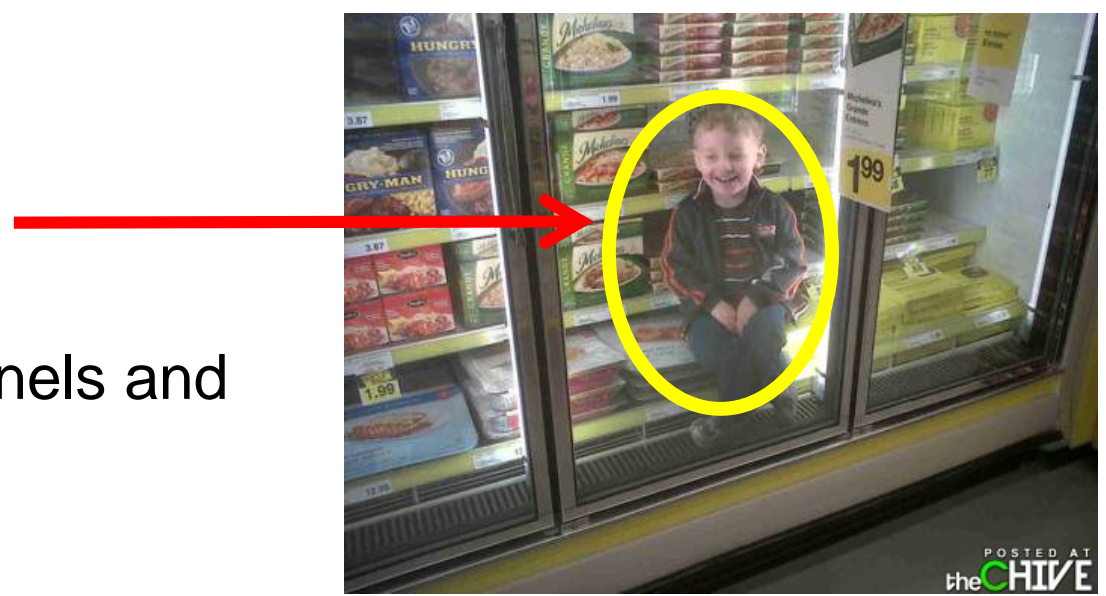


3. Increase store profitability

Grocery Stores Set Normative Purchasing Behavior

- Which would lead you to buy more?

- Limit 18/person vs. No Limit/person

-4 for $\$ 4.00 \quad$ vs. 1 for $\$ 1.00$ 
3. Increase store profitability

Grocery Stores Set Normative Purchasing Behavior

- What if we set NORMS in the grocery store for more nutritive foods?

\section{Examples}




\section{Example \#1}

The Half Cart

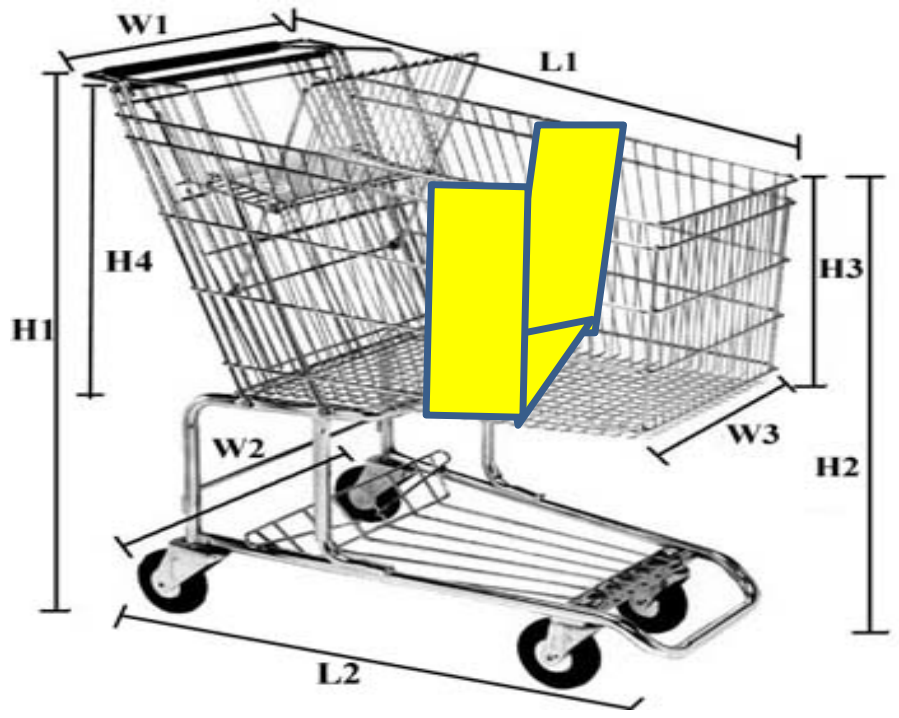

1. Salient

2. Easy to Interpret

3. Easy to Compare Against Current Behavior 


\section{Example \#1}

The Half Cart
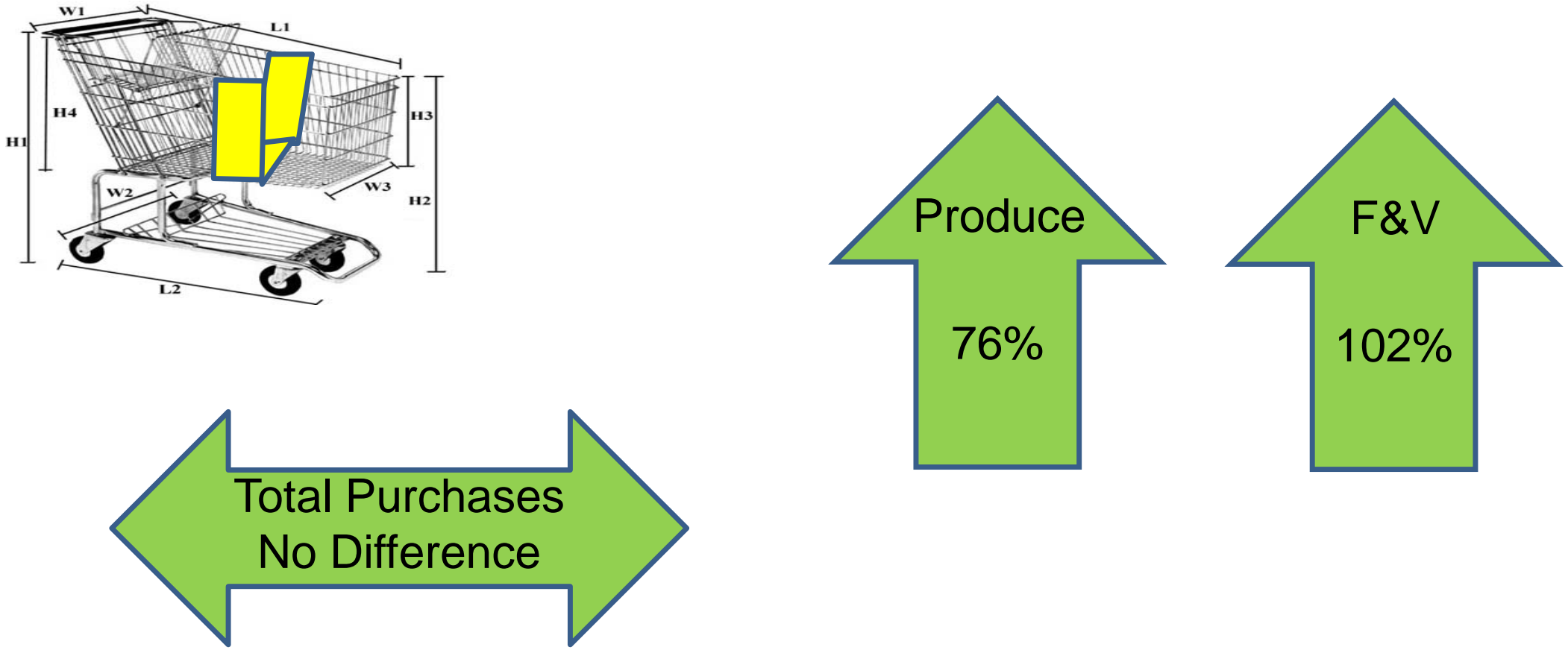


\section{Example \#2: Floor Stickers(or Mats)}

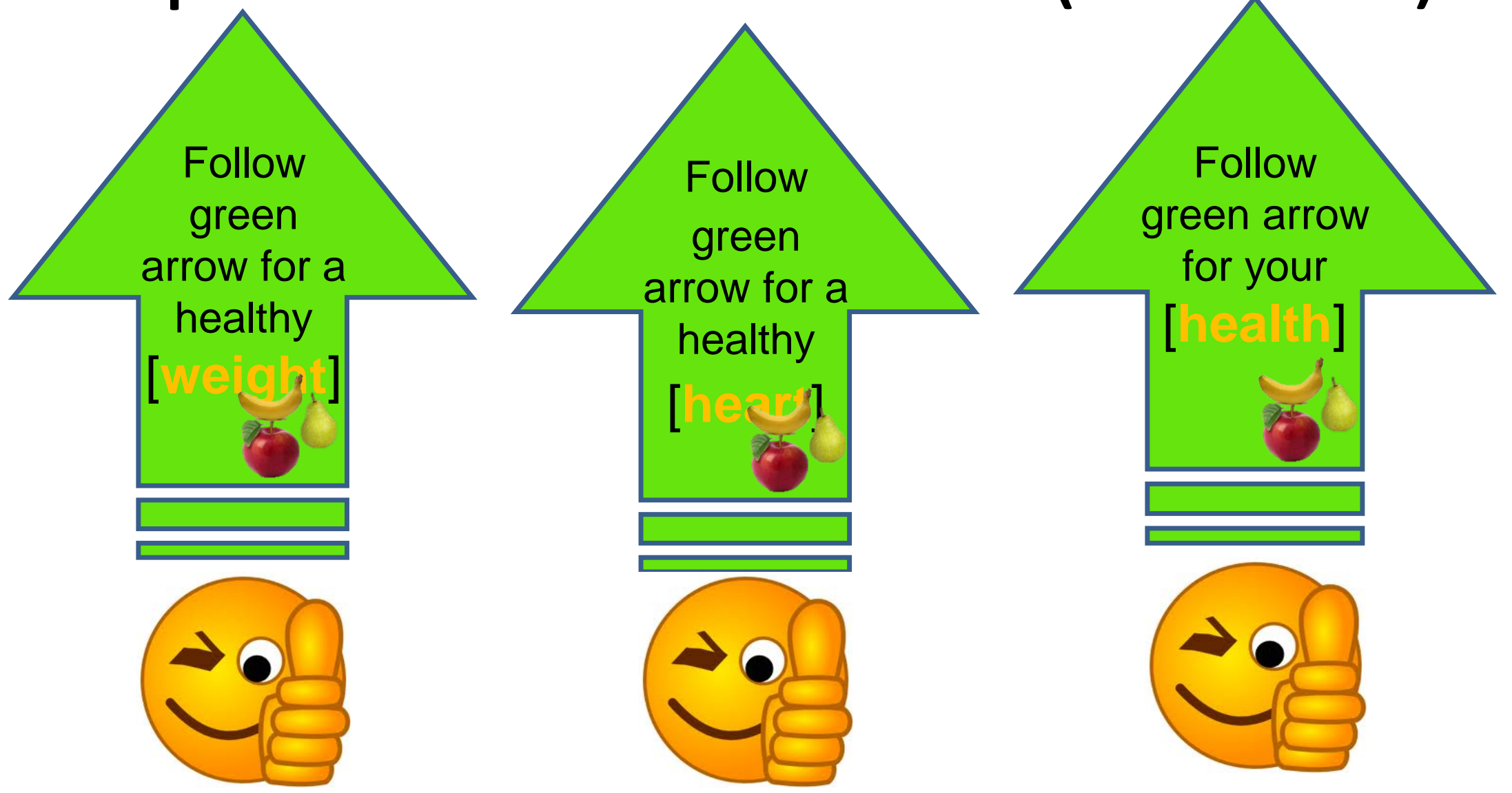

1. Salient

2. Easy to Interpret

3. Easy to Compare Against Current Behavior 


\section{Example \#2: Floor Stickers(or Mats)}

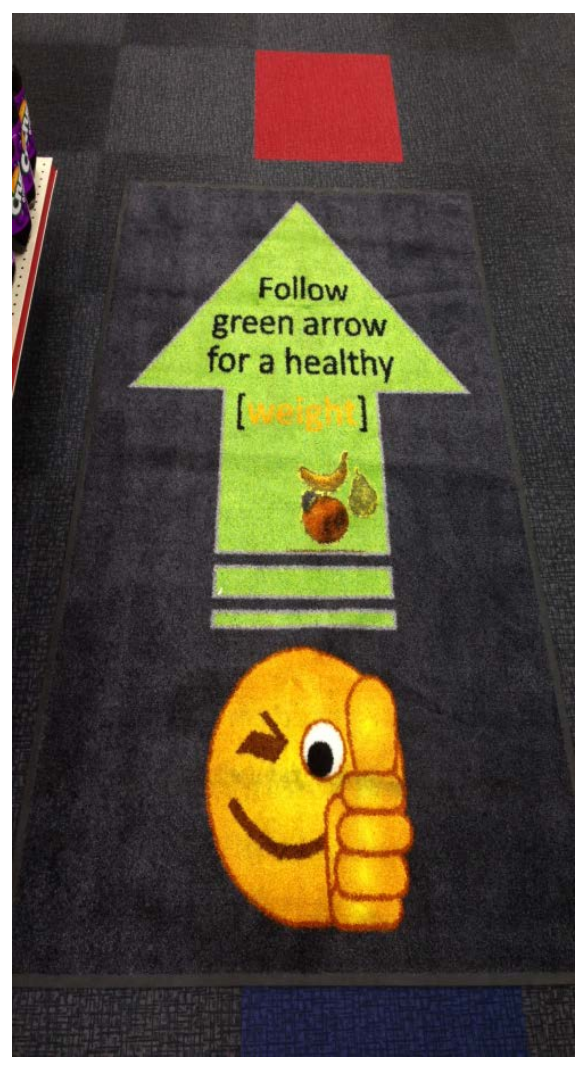

- Collection of 207,633 person grocery store transactions as daily sales reports
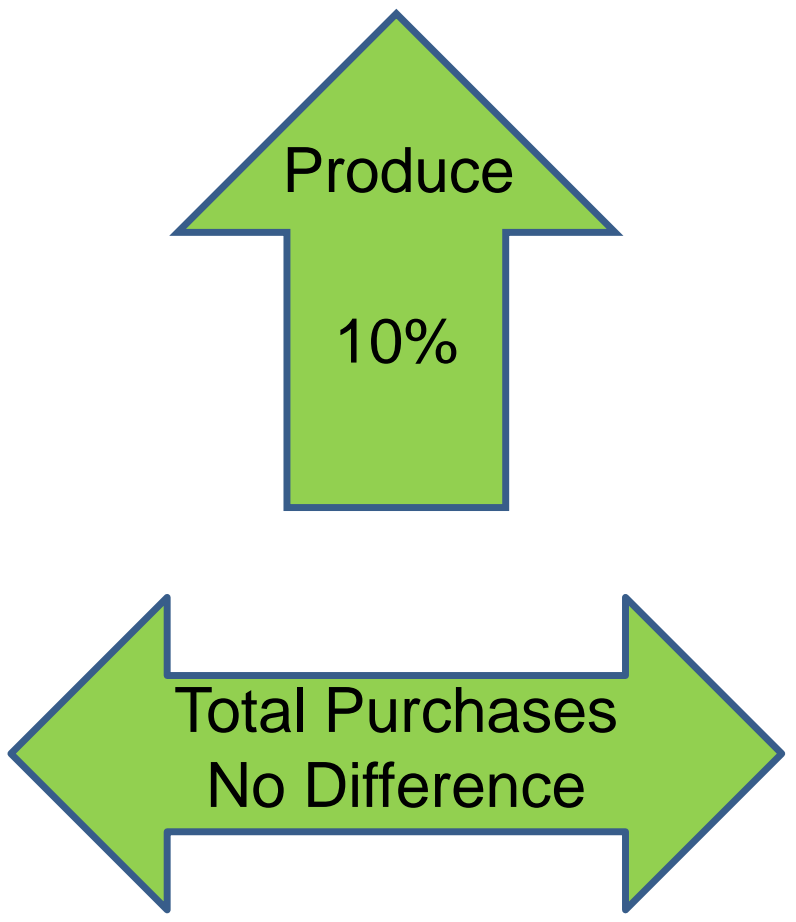


\section{Example \#3: Grocery Cart Placards}

En Esta Tienda, La Mayoría de

$$
\begin{gathered}
\text { la Gente Elige al Menos } \\
5 \text { Frutas y Verduras }
\end{gathered}
$$

Los más Populares: Plátanos, Limones, Aguacates, Maíz, Naranjas, Tomates, Jalapeño, Pimientas Verdes, Cebollas, y Duraznos

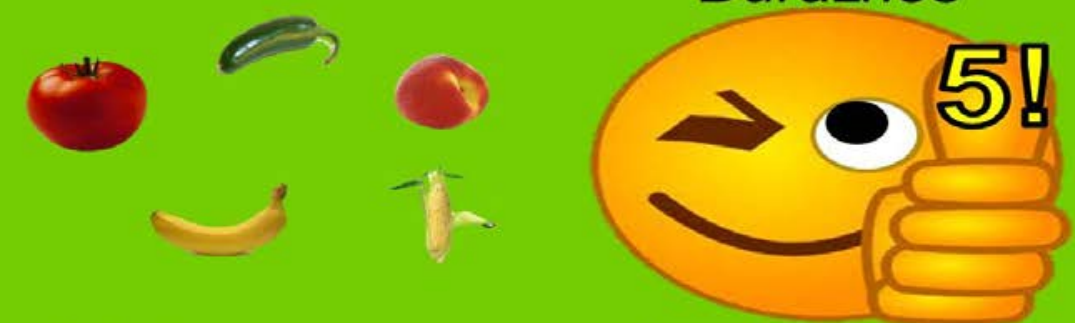

In This Store, Most People Choose at Least 5 Produce Items Most Popular: Bananas, Limes, Avocados, Corn, Oranges, Tomatoes, Jalapeno \& Long Green Peppers, Onions, and Peaches

1. Salient

2. Easy to Interpret

3. Easy to Compare Against Current Behavior 


\section{Example \#3: Grocery Cart Placards}
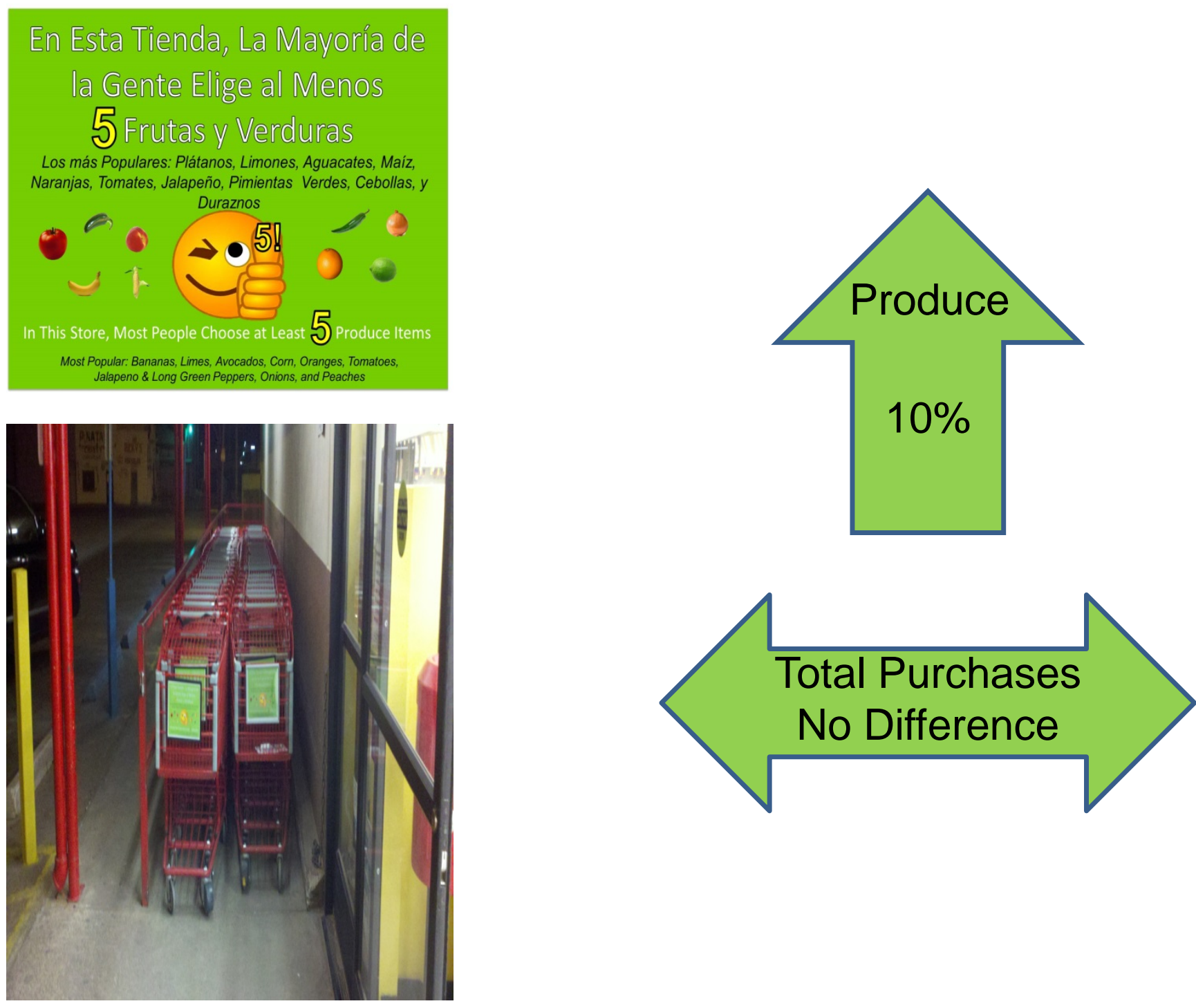


\section{How Did We Do?}

\section{Shopper Marketin for Dieticians}

1. Improve Nutrition

2. Keep constant shoppers' budg t

3. Increase store profitability

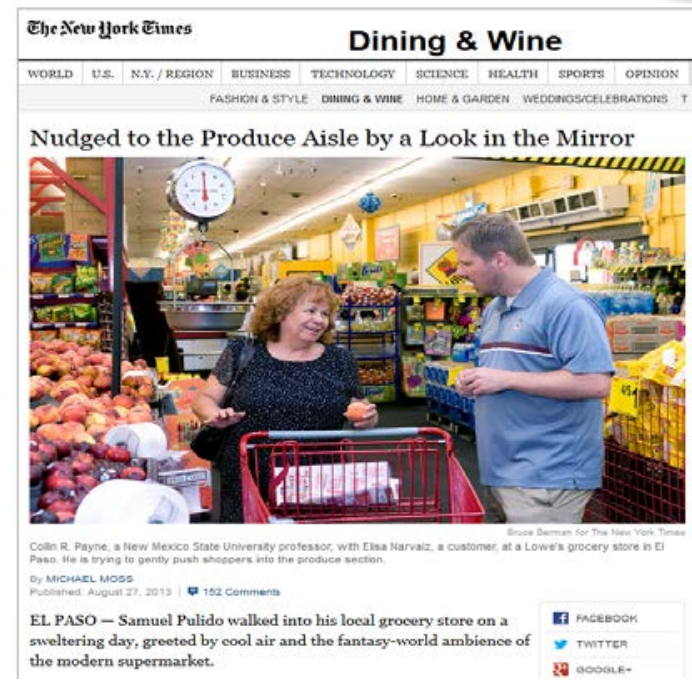




\section{What's next?}

1. Working w/USDA to move SNAP WIC participants to $F \& V$ purchases

2. Sales Circular Configuration to boost F\&V purchases

3. Traffic control system to boost F\&V

4. Mirrors in grocery carts 
Thank you!

Email: crp@nmsu.edu 


\section{References}

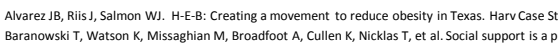
Beatty SE, Ferrell, ME. Impulse buying: modeling its precursors. Jof Retaliling 1998; 74(2): 169-9.

Belk RW. The ineluctable mysteries of possessions. J Joc Behav Pers 1991; 6 (6): 17-55.

Berger J, Heath C. Where consumers diverge from others: Identity signaling and product domains. IConsum Res 2007; 34, $121-34$.

J Consum Res 2008; 35: 509-518.

Brown T, Bruns E. F Fruit and vegetable redemption rates show significant increase. Texas WIC News $2011 ; 20,2$ (March/A April): 8-10.

Cassgrande SS, Wang Y, Anderson C, Gary TL. Have Americans increased their fruit and vegetable intake? Am I Prev Med 2007; 32(4): 257-63.

c..gov/nchs/fastats/overwt.htm laccessed October 2013)

Cialdini RB, Kallgren CA, Reno RR.A A focus theory of normative conduct. Adv Exp Soc Psychol 1991; 24:201-34.

Clee MA, Wicklund RA. Consumer behavior and psychological reactance. J Consum Res 1980; 644, 389-405.

Clement J. Jisual influence on in-store buying decsions: an eve-track experiment on the visualim

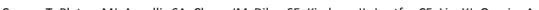

Ermakov IV, Gellermann W. Validation model for Raman based skin carotenoid detection. Arch Biochem Biophys 2010; 504(1): 40-9.9.

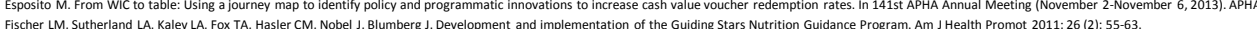

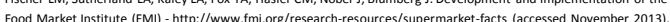

icing, and environmental change. Prev Med 2004; 39, 75-80.

Gleason S, Pooler J. The Effects of Changes in WIC Food Packages on Redemptions. USDA 2011, FANRP C

Grocern

Grocerry Manufacturers Association (GMA), Deloitte Consulting LP. Shopper marketing: Capturing a shopper's mind, heart and wallet. 2007: 1-32.

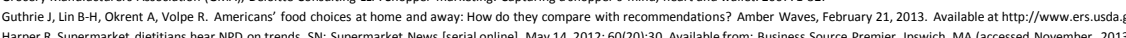

Hauser JR, Urban GL. The value priority hypotheses for consumer budget plans.J Consum Res $1986 ; 12$ (March): 446 -62.

Hedley AA, ogden CL, Johnson CL, Carroll MD, Curtin LR, Flegal KM. Prevalence of overweight and obesty among US children, adolescents, and adults, 1999-2002.JAMA 2004; 291 223: 2847-50.

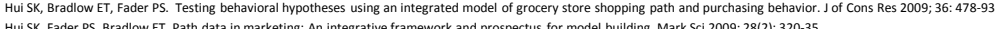

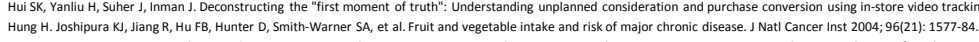

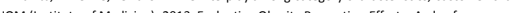

Johnson MD. The differential processing of product category and noncomparable choice alternatives. J Consum Res 1989; 16 (December): 300-9.

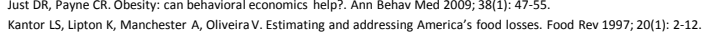

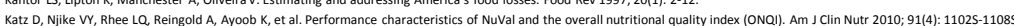

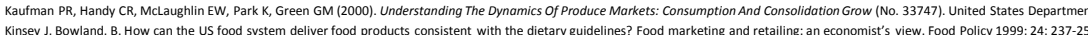

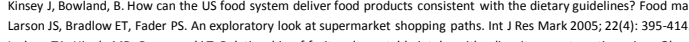

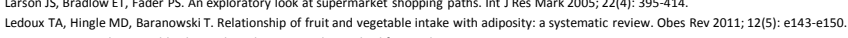

Av Consum Res 2011; 39: 185-6.

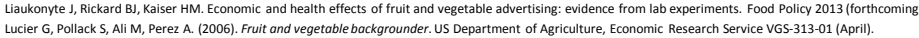

tucier G, Pollack S, Ali M, Perez A. (2006). Fruit and vegetable backgrounder. US Department of Agriculture, Economic Research Service VGS-313-01 (April).

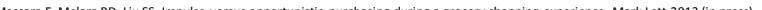

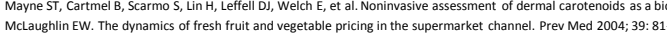

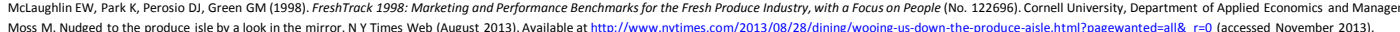

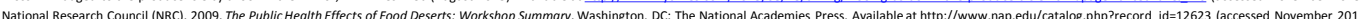

Neff J. What's in store: the rise of shopper marketing. Advert Age 2007; 78: 1-2.

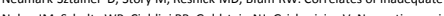

Novensty $N$, Ka

Payne CP. Niculescu M Social meaning in supermarkets as a direct route to improve parents' frit and vegetable purchases. Aric Resour Econ Rev 2012; 411(1): 124-37.

Payne CR, Niculescu M, Just DR, Reynolds A. Behavioral economic approaches to grocery store health interventions. (Invited Symposium Presentation). Stuty O

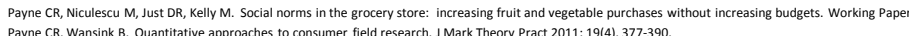

at https://www.prismskylabs.com/solutions/ (accessed November 2013/

Reno RR, Cialdinin RB, Kallgren CA. The transsituational influence of social norms.J Pers Soc Psychol 1993; 64(1): 104-12

Robinson E. Thomas I I An tood tess: The impact of social influence on food liking evaluations in temale students. PLos One 2012; 7 (11): e48858.

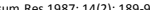

Salmon S, Fennis BM, de Ridder DTD, Adriaanse MA, de Vet E. Health on impulse: When low self-co

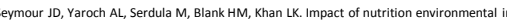

Sorensen H. The science of shopping. Mark Res 2003; 15(3): 30-5.5

Silley KM, Inman J, Wakefield KL. Planning to make unplanned purchns,

Stilley KM, Inman IJ, Wakefield KL. Spending on the fly: mental budgets, promotions, and spending behavior. Jof Mark 2010; 74: 34

ing: list and non-list usage. Mark Intelligence \& Planning 2004; 22(6): 623-35.

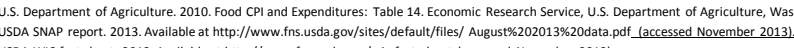

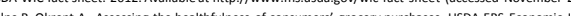

Wansink B, Payne CR, Herbst K, Soman D. Part Carts: Assortment allocation cues that increase fruit and vegetable purchases. INutr Educ Behav 2013; $45 / 45$ ): s42

White K, Simpson B. When do (and don't) normative appeals influence sustainable consumer behaviors? J of Mark 2013; 77: 78-95.

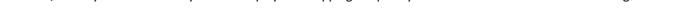

